Grażyna PIECHOTA

Krakowska Akademia im. A. Frycza Modrzewskiego

\title{
Źródła poparcia wyborczego lokalnych liderów w samorządowych kampaniach wyborczych (na przykładzie kampanii wyborczych prezydentów miast na prawach powiatu w 2010 roku)
}

\begin{abstract}
Wstęp
nalizując proces ubiegania się lokalnych liderów o władzę w samorządzie gminnym zastanawiające są, od czasu zmiany z wyborów pośrednich na bezpośrednie, głównie dwa zagadnienia. Pierwszy, to niska frekwencja wyborcza (średnio nieprzekraczająca 50\%), co wydaje się zaskakujące w wyborach dotyczących władz lokalnych, które podejmują najważniejsze decyzje dla mieszkańców. Drugi natomiast, to zasadniczo reelekcja lokalnych polityków na kolejne kadencje i ujawniający się brak zdolności do kreacji innych lokalnych liderów, których wybór wpływałby na uwzględnianie w podejmowanych decyzjach nowych pomysłów, idei czy odmiennego spojrzenia na problemy lokalnej społeczności i możliwości ich rozwiązywania. Wybór nowych liderów kreowałby także możliwość angażowania innych pokładów lokalnego kapitału społecznego. Polskie prawo nie reguluje kadencyjności, co oznacza, że prezydenci, burmistrzowie czy wójtowie mogą sprawować władzę tak długo, jak długo są wybierani przez lokalną społeczność, albo jak długo do wyborów przystępują. Tym samym rekordziści rządzą w swoich gminach po kilkanaście lat (przykładem rekordzisty w długości sprawowania władzy w miastach na prawach powiatu był prezydent Chorzowa - Marek Kopel, który utracił władzę kilkunastoma głosami przewagi kontrkandydata, w II turze, w wyborach w 2010 r. Rządził w Chorzowie od 1991 r., czyli łącznie 19 lat). Tymczasem sprawując władzę liderzy dysponują określonymi narzędziami, które w przypadku braku określenia kadencyjności oraz przy niskiej frekwencji wyborczej, pozwalają na skuteczny wybór na kolejną kadencję.

Artykuł stanowi próbę uporządkowania i wskazania najważniejszych źródeł systemowego i pozasystemowego poparcia, dzięki którym lokalni
\end{abstract}


liderzy uzyskują poparcie wyborcze, pozwalające na zdobycie albo utrzymanie władzy. W badaniach skoncentrowano się tylko na zbadaniu źródeł poparcia, które uzyskują liderzy polityczni w miastach na prawach powiatu, w kampanii wyborczej, która odbyła się w 2010 roku. Badania zostały zrealizowane z pozyskanego grantu MNiSW na badania statutowe w Krakowskiej Akademii im. Andrzeja Frycza Modrzewskiego w 2012 roku. W artykule wykorzystano także część badań zrealizowanych i opublikowanych wcześniej, a dotyczących procesów komunikacji politycznej prowadzonej przez lokalnych liderów w social mediach (Facebook i polityczne blogi) oraz z wykorzystaniem stron internetowych. W tym tekście zawarto pełne zestawienie wyników tychże badań, w kontekście komunikacji politycznej w procesie wyborczym.

\section{Metodologia badań}

Badania zrealizowano wykorzystując powszechnie dostępne źródła. Skoncentrowano się na dokumentach oficjalnie udostępnianych w BIP miast na prawach powiatu, dokumentach statystycznych oraz innych, w tym zestawieniach przygotowywanych do rankingu miast, w zakresie pozyskiwanych środków unijnych. Ta formuła przeprowadzenia badań związana była $\mathrm{z}$ trudnościami, które powstały w związku $\mathrm{z}$ ankieta, która pierwotnie wysłano do wszystkich, tj. 65 miast na prawach powiatu. Ankieta została wypełniona tylko przez przedstawicieli 10 miast (co dawało zwrotność na poziomie 15\%, niereprezentatywną dla przyjętej grupy badawczej). Zwrotność ankiety na podanym poziomie nie pozwoliła na rzetelne zrealizowanie badania, w tym zakresie, w jakim badanie zaplanowano, podjęta została decyzja o zmianie realizacji badań. W ramach badań:

1) przeanalizowano dane $\mathrm{z}$ BIP urzędów miast na prawach powiatu $\mathrm{w}$ zakresie informacji dotyczących przynależności klubowej radnych rad miasta (analizowano składy rad miasta po wyborach w 2010 r., dane zestawiono z BIP w czerwcu i lipcu 2012 r. w takim zakresie, w jakim rady miasta poszczególnych miast udostępniły informacje);

2) przeanalizowano uchwały, udostępnione w BIP miast na prawach powiatu, które w miesiącach styczeń-listopad $2010 \mathrm{r}$. podejmowały rady miast, w kontekście inwestycji i projektów dedykowanych wybranym grupom mieszkańców - wyborców. Brano pod uwagę wyłącznie te 
uchwały, które były podejmowane, jako nowe, a nie zmieniane, we wskazanych miesiącach. Łącznie przeanalizowano 12004 uchwał (z 65 miast, 7 miast nie udostępnia uchwał na swoich stronach, albo dostęp do tych zasobów był nieaktywny w okresie poboru danych do realizowanych badań - lipiec 2012 r.);

3) wystosowano pismo, w dniu 16 kwietnia 2012 r., do Krajowego Biura Wyborczego w celu uzyskania informacji o liczbie i wyniku referendów, które odbyły się w kadencji 2006-2010 i dotyczyły odwołania prezydentów miast na prawach powiatu;

4) przeanalizowano dane statystyczne (GUS) dotyczące wysokości dochodów i wydatków budżetowych na 1 mieszkańca w badanych miastach, poziomu bezrobocia w kadencji 2006-2010.

5) przeanalizowano dane dotyczące wysokości środków unijnych, pozyskiwanych przez miasta na prawach powiatu, z udostępnionego rankingu dziennika „Rzeczpospolita” przygotowane na koniec 2009 r. - http://www.rp.pl/artykul/509748,511633-Tabele-z-rankingiem-samorzadow-2010.html (dostęp czerwiec/lipiec 2012 r.);

6) częściowo zrealizowano, a częściowo wykorzystano opublikowane wcześniej badania ${ }^{1}$, w zakresie korzystania przez polityków z social mediów w kampaniach wyborczych oraz podczas sprawowania władzy. Przeanalizowano czy politycy korzystają z social mediów (polityczne blogi, Facebook) oraz w jaki sposób komunikują się z wykorzystaniem stron internetowych, oraz jakie treści przekazują do opinii publicznej;

7) wykorzystano wyniki badań ilościowych zrealizowanych, przez autorkę w 2011 r., w zakresie funkcjonowania mediów samorządowych w miastach na prawach powiatu - czy w miastach takie media są wydawane, w jakiej formie, jakie treści są za ich pośrednictwem przekazywanie oraz $\mathrm{w}$ jaki sposób ten kanał komunikowania się z lokalną społecznością wpływa na uzyskiwane poparcie wyborcze.

Zob. G. Piechota, Application of social media in political communication of local leaders in election processes (on example of Facebook's use by majors of voivodship cities in Poland in the 2010 election campaign), ,Central European Political Studies” 2011, nr 4 Wydawnictwo Naukowe WNPiD, Poznań oraz G. Piechota, Wykorzystanie serwisu społecznościowego Facebook $w$ komunikacji politycznej miast Metropolii Silesia I ich prezydentów, „Studia Medioznawcze” 2012, nr 1(48), Wydawnictwo Aspra, Warszawa. 


\section{Wyniki badań}

Wyniki badań zostały zestawione i opracowane w wyodrębnionych blokach tematycznych. Wnioski zostały uwzględnione w każdym z analizowanych bloków oraz zbiorczo w podsumowaniu.

\section{Poparcie partii politycznych i lokalnych organizacji obywatelskich}

Poparcie udzielane lokalnym liderom przez partie polityczne albo lokalne organizacje obywatelskie ${ }^{2}$ może być analizowane w kilku kontekstach. Jako poparcie udzielane liderowi, który jest członkiem partii/liderem organizacji, i którego partia/organizacja popiera w kampanii oraz jako osobę, którą wspierają i zarazem promują, w lokalnej kampanii, członkowie partii/organizacji, sami także ubiegający się o wybór na stanowisko radnych. W obu przypadkach można mówić o systemowym źródle poparcia lokalnego lidera, wynikającym z poparcia oraz organizacji kumulujących kapitał społeczny na poziomie lokalnym, niezwiązanych $\mathrm{z}$ partiami.

Badania wskazały, iż na 65 prezydentów miast na prawach powiatu, wybranych w wyborach samorządowych w 2010 roku, w 27 miastach prezydenci i większość radnych $\mathrm{w}$ radzie miasta pochodzą $\mathrm{z}$ tego samego ugrupowania (partii lub organizacji), w 17 przypadkach prezydent rządzi bez większości w radzie miasta, natomiast w 21 przypadkach nie udało się ustalić składów rady miasta, jak chodzi o przynależność radnych do poszczególnych klubów (w BIP badanych 21 rad miasta takie informacje nie zostały podane). Te dane, wskazują, iż w wyborach poparcie wynikające z przynależności do partii albo do organizacji ma znaczenie i wywołuje korelację pomiędzy wyborem lidera na prezydenta miasta a wyborem większości radnych do rady miasta, reprezentujących tę samą partię czy organizację. W pierwszej turze w 2010 roku wybrano 15 prezydentów (przy jednoczesnej większości w radzie miasta), w drugiej turze 12 . $\mathrm{Z}$ kolei w przypadku prezydentów rządzących bez większości w radzie miasta pochodzącej z ugrupowania, które reprezentował, w wyborach, prezydent, w pierwszej turze wybrano 9 prezydentów, w drugiej 8. Analizując te dane także zauważalna staje się korelacja po-

2 Dalej używane są skróty: partia i organizacja. 
między wyborem prezydenta a wyborem radnych z tego samego ugrupowania, co może świadczyć o istnieniu wzajemnie wspierającego się mechanizmu promowania poszczególnych lokalnych polityków.

W 2010 roku na 65 prezydentów powołano 15 nowych (9 prezydentów nie uzyskało reelekcji, w 2 miastach rządzili komisarze po referendach, w których odwołano prezydentów, w 4 miastach prezydenci nie ubiegali się o reelekcję), 50 pozostałych skutecznie ubiegało się o reelekcję. W tej grupie zauważalne staje się tracenie poparcia przez lokalne organizacje obywatelskie na rzecz partii politycznych. Z grupy 15 nowych prezydentów, w 6 miastach, gdzie do końca kadencji w 2010 roku władzę sprawował prezydent z lokalnego ugrupowania obywatelskiego, po wyborach w 2010 roku władza przeszła na prezydenta z poparciem Platformy Obywatelskiej ${ }^{3}$. W 1 przypadku władzę stracił prezydent popierany przez PO na rzecz prezydenta reprezentującego ugrupowanie obywatelskie, w 3 przypadkach władza przeszła z prezydentów reprezentujących inne partie polityczne (1 - Sojusz Lewicy Demokratycznej, 2 - Prawo i Sprawiedliwość ${ }^{4}$ ) na PO. W 2 przypadkach prezydenci się zmienili, jednak władza pozostała w ramach tych samych ugrupowań (1 - SLD, 1 - PO). W 1 przypadku władza przeszła z prezydenta reprezentującego jedno ugrupowanie obywatelskie na rzecz innego ugrupowania, również lokalnego, obywatelskiego. PO straciła urząd prezydenta na rzecz kandydata reprezentującego ugrupowanie obywatelskie tylko w 1 przypadku. Powyższe dane, związane ze zmianami na stanowiskach prezydentów miast po wyborach w 2010 roku wskazują odmienną tendencję, niż jeszcze kilka lat temu. Otóż skuteczniejsze poparcie wyborcze płynie z ugrupowań partyjnych, jak chodzi o zdolność do kreacji nowych lokalnych liderów (kandydatów wygrywających wybory na stanowiska prezydentów miast). Dodać należy, że PO, jako partia polityczna w 2010 roku wygrała w wyborach do samorządów wszystkich województw, wcześniej, w czerwcu 2010 r., wygrała wybory prezydenckie. Jednocześnie w 15 miastach, w których po wyborach objęli stanowiska nowi prezydenci, w 5 miastach zarazem większość mandatów $\mathrm{w}$ radach ${ }^{5}$ miasta także objęta została przez radnych pocho-

3 Dalej w tekście używany będzie skrót nazwy partii - PO.

4 Dalej w teście używane będą skróty nazw obu partii - SLD i PiS.

5 Większość w tym kontekście jest traktowana, jako większość nominalna, nie analizowano, czy dla posiadania większości w głosowaniach w radzie miasta zawierano koalicje polityczne. 
dzących z PO. W 7 miastach nie udało się ustalić przynależności klubowej radnych, w 1 mieście rządzi prezydent z PO przy większości z ugrupowania obywatelskiego, w 1 mieście sytuacja jest odwrotna - prezydent pochodzi z ugrupowania obywatelskiego, a większość w radzie z PO. Natomiast w 1 przypadku prezydent pochodzi z SLD, a radni w radzie miasta sa w takiej samej liczbie z PiS oraz z ugrupowania obywatelskiego.

Powyższa analiza poparcia wyborczego, które płynęło w wyborach samorządowych w 2010 roku z partii politycznych lub z ugrupowań obywatelskich wskazała, że sprawująca władzę w czasie wyborów partia polityczna - PO, posiada wyższą niż inne ugrupowania polityczne, ale także ugrupowania obywatelskie, zdolność do kreacji liderów na poziomie lokalnym. Spośród 16 prezydentów miast, sprawujących władzę z poparciem PO, aż 10 sprawuje ją po wygranych wyborach w 2010 roku (w 6 przypadkach władza przed wyborami w 2010 roku należała do kandydata wspieranego przez lokalne ugrupowanie obywatelskie i w 5 miastach głównym kontrkandydatem na prezydenta z PO był przedstawiciel lokalnego ugrupowania obywatelskiego - wyjątkiem była Łódź, gdzie kandydatka z PO zmierzyła się z kandydatem z SLD).

2. Polityka protestu - jako źródło kreacji nowych liderów lokalnych

Rosnące znaczenie polityki protestu, jako egzemplifikacji aktywności społeczeństwa obywatelskiego działającego w opozycji wobec rządów, także lokalnych, i polityki realizowanej przez lokalne władze, ma coraz istotniejsze znaczenie $\mathrm{w}$ procesie zarządzania lokalną społecznością. Wskazując na rosnące znaczenie wspólnie podejmowanych działań „w opozycji” dla aktywności lokalnej władzy, trudno nie zwrócić uwagi na wymiar wyborczy polityki protestu. Odwołanie urzędujących władz (prezydenta) wywołuje efekt w postaci konieczności powołania nowych władz, tym samym polityka protestu dopuszcza do decydowania wyborców, jednocześnie tworząc systemową konieczność kreacji nowego lokalnego lidera. W kadencji 2006-2010 w miastach na prawach powiatu zarządzono 6 referendów w sprawie odwołania prezydentów miast.

Poniższa tabela, sporządzona została na podstawie pisma otrzymanego z Krajowego Biura Wyborczego w Warszawie ${ }^{6}$.

6 Pismo nr ZPOW-066-6/12 z dnia 16 maja 2012 r. otrzymano, jako odpowiedź na pismo wystosowane przez badającego, w trybie ustawy o dostępie do informacji publicznej, w celu podania danych, ujętych w tabeli - jak wyżej. 


\begin{tabular}{||c|l|l|c|c|l||}
\hline Lp. & $\begin{array}{c}\text { Data } \\
\text { referendum }\end{array}$ & $\begin{array}{c}\text { Organ } \\
\text { odwolywany }\end{array}$ & Frekwencja & $\begin{array}{c}\text { Ważność } \\
\text { referendum }\end{array}$ & \multicolumn{1}{|c||}{$\begin{array}{c}\text { Wynik } \\
\text { referendum }\end{array}$} \\
\hline 1. & 6 lipca 2008 & $\begin{array}{l}\text { Prezydent Miasta } \\
\text { Skierniewice }\end{array}$ & $6,79 \%$ & nieważne & $\begin{array}{l}\text { Frekwencja niewystar- } \\
\text { czająca }\end{array}$ \\
\hline 2. & $\begin{array}{l}16 \text { listopada } \\
2008\end{array}$ & $\begin{array}{l}\text { Prezydent Miasta } \\
\text { Olsztyn }\end{array}$ & $32,38 \%$ & ważne & $\begin{array}{l}\text { Prezydent Miasta został } \\
\text { odwołany }\end{array}$ \\
\hline 3. & $\begin{array}{l}17 \text { maja } \\
2009\end{array}$ & $\begin{array}{l}\text { Prezydent Miasta } \\
\text { Sopotu }\end{array}$ & $40,02 \%$ & ważne & $\begin{array}{l}\text { Prezydent Miasta nie } \\
\text { został odwołany }\end{array}$ \\
\hline 4. & $\begin{array}{l}8 \text { listopada } \\
2009\end{array}$ & $\begin{array}{l}\text { Prezydent Miasta } \\
\text { Gliwice }\end{array}$ & $11,74 \%$ & nieważne & $\begin{array}{l}\text { Frekwencja niewystar- } \\
\text { czająca }\end{array}$ \\
\hline 5. & $\begin{array}{l}15 \text { listopada } \\
2009\end{array}$ & $\begin{array}{l}\text { Prezydent Miasta } \\
\text { Częstochowy }\end{array}$ & $21,32 \%$ & ważne & $\begin{array}{l}\text { Prezydent Miasta został } \\
\text { odwołany }\end{array}$ \\
\hline 6. & $\begin{array}{l}17 \text { stycznia } \\
2010\end{array}$ & $\begin{array}{l}\text { Prezydent Miasta } \\
\text { Łodzi }\end{array}$ & $22,20 \%$ & ważne & $\begin{array}{l}\text { Prezydent Miasta został } \\
\text { odwołany }\end{array}$ \\
\hline
\end{tabular}

Źródlo: Opracowanie na podstawie tabeli otrzymanej w piśmie KBW.

Jak wskazano w piśmie, otrzymanym z Krajowego Biura Wyborczego, z wyjątkiem referendum w sprawie odwołania Prezydenta Miasta Olsztyn, które było przeprowadzone z inicjatywy Rady Miasta Olsztyna, wszystkie pozostałe były przeprowadzone $\mathrm{z}$ inicjatywy mieszkańców.

Spośród 6 referendów w miastach na prawach powiatu, 2 były nieważne ze względu na nieuzyskanie wystarczającej frekwencji wyborczej. Jedno referendum - w sprawie odwołania prezydenta Sopotu było ważne, ale mieszkańcy nie wyrazili chęci odwołania prezydenta, głosowali za kontynuacją kadencji wybranego w 2006 roku prezydenta. Natomiast w 3 przypadkach referenda zakończyły się odwołaniem prezydentów. W Olsztynie powodem organizacji referendum (z inicjatywy Rady Miasta) były sprawy obyczajowe i toczące się przeciwko prezydentowi postępowania w sprawach karnych. Po skutecznym odwołaniu prezydenta w referendum, po przedterminowych wyborach prezydentem został kandydat PSL (wygrał wybory z kandydatem PO). Z kolei zarówno w Łodzi, jak i w Częstochowie nie odbyły się przedterminowe wybory, do końca kadencji w 2010 r. władzę sprawowali komisarze z PO. I tak, w Łodzi prezydent odwołany został z inicjatywy mieszkańców (wspieranych przez SLD), głównie z powodu braku inwestycji w mieście oraz wydawania pieniędzy publicznych przez prezydenta na podróże zagraniczne, zaś w Częstochowie prezydentowi zarzucano brak inwestycji i rozwoju miasta oraz nadmierne koncentrowanie się na realizacji inwestycji na rzecz Jasnej Góry. Wybory w 2010 roku w Łodzi wygrał kandydat PO (II tura, 
w pojedynku z kandydatem SLD), w Częstochowie - kandydat SLD (II tura, w pojedynku z kandydatką PO). Analizując te dwie sytuacje - w Łodzi oraz w Częstochowie nasuwa się wniosek, iż odwołanie urzędującego prezydenta przez mieszkańców wspieranych przez partie polityczne nie wiąże się z jednoczesnym wyłonieniem kandydata na lokalnego lidera, związanego z partią polityczną, która wspierała odwołanie prezydenta w referendum. W Częstochowie, wspierająca odwołanie prezydenta PO nie zdołała wykreować lidera i wygrać wyborów w 2010 r., zaś w Łodzi SLD wspierająca odwołanie prezydenta w referendum przegrała wybory w 2010 r. na rzecz kandydatki z PO.

3. Kryteria ekonomiczne: pozyskiwanie środków unijnych, bezrobocie, najwyższe dochody budżetowe i najwyższe wydatki budżetowe na mieszkańca

Czynniki ekonomiczne, kształtujące warunki życia w miastach, poziom rozwoju czy poziom bezrobocia zostały przeanalizowane, jako te, które mogą wpływać na poparcie wyborcze lokalnych liderów - tych ubiegających się o reelekcję. Z kolei niezadowolenie z poziomu życia może uchodzić za powód wpływający na kształtowanie nowych liderów, budujących kapitał na tym niezadowoleniu społecznym wywołanym czynnikami ekonomicznymi lub oferujących inne propozycje zarządzania sprawami lokalnymi, związanymi ze sferą ekonomiczną.

Najwyższe dochody budżetowe (w złotych) na mieszkańca (na koniec 2010 r.) w miastach na prawach powiatu zanotowano w:

1) Sopocie - 8664,92 (reelekcja prezydenta w II turze);

2) Warszawie - 6084,93 (reelekcja prezydenta w I turze);

3) Wrocławiu - 5010,18 (reelekcja prezydenta w I turze);

4) Tarnobrzegu - 4919,66 (nowy prezydent «PiS $\rightarrow$ PO» od 2010 r., wybór w II turze);

5) Płocku - 4868,24 (nowy prezydent «PiS $\rightarrow \mathrm{PO} »$ od 2010 r., wybór w II turze);

6) Przemyślu - 4657,62 (reelekcja prezydenta w I turze);

7) Krosno - 4648,83 (reelekcja prezydenta w I turze);

8) Świnoujście - 4573,47 (reelekcja prezydenta w I turze);

9) Kielce - 4491,31 (reelekcja prezydenta w I turze);

10) Kraków - 4479,95 (reelekcja prezydenta w II turze);

11) Gdańsk - 4439,07 (reelekcja prezydenta w I turze); 
12) Poznań - 4418,00 (reelekcja prezydenta w II turze);

13) Katowice - 4329,54 (reelekcja prezydenta w I turze);

14) Tychy - 4317,14 (reelekcja prezydenta w I turze);

15) Nowy Sącz - 4306,11 (reelekcja prezydenta w I turze);

16) Opole - 4300,16 (reelekcja prezydenta w II turze);

17) Konin $-4375,44$ (nowy prezydent «SLD $\rightarrow$ SLD» od 2010 r., wybór w II turze);

18) Suwałki - 4274,31 (reelekcja prezydenta w I turze);

19) Białystok - 4263,21 (reelekcja prezydenta w I turze).

W 19 spośród 65 miast, w których zanotowano najwyższe dochody budżetowe na mieszkańca znajdują się 3 miasta, w których prezydenci zanotowali rekordowe poparcie wyborcze, wygrywając w pierwszej turze (Wrocław - 71,62\%, Białystok - 68,53\%, Krosno - 77\%). Spośród 19 prezydentów, aż 12 zdobyło reelekcję w pierwszej turze, w 3 przypadkach prezydenci stracili władzę (w 1 władza przeszła na innego prezydenta $\mathrm{w}$ ramach tego samego ugrupowania, poprzednik nie ubiegał się o reelekcję, w 2 władzę stracili prezydenci z PiS na rzecz kandydatów z PO). Te dane prezentują, że poziom życia mierzony kryterium wysokich średnich dochodów budżetowych jest czynnikiem wpływającym na ocenę polityka w kontekście jego zdolności do utrzymywania władzy. Dwa przypadki utraty władzy sprawowanej przez liderów przynależących do partii politycznej na rzecz liderów przynależących lub popieranych przez inną partię polityczną może potwierdzać wcześniejszy wniosek, iż partia polityczna, która sprawuje władzę posiada zdolność do skuteczniejszego kreowania nowych liderów ${ }^{7}$.

Najwyższe wydatki budżetowe (w złotych) na mieszkańca (na koniec 2010 r.) w miastach na prawach powiatu zanotowano w:

1) Sopocie - 7924,73 (reelekcja, II tura);

2) Warszawie - 6630,69 (reelekcja, I tura);

3) Wrocławiu - 5721,22 (reelekcja, I tura);

4) Tychach - 5289,49 (reelekcja, I tura);

5) Zabrzu - 5065,29 (reelekcja, I tura);

6) Płocku - 4907,05 (nowy prezydent «PiS $\rightarrow$ PO» od 2010 r., wybór w II turze);

7 Prezydent Tarnobrzegu w wyborach reprezentował lokalne ugrupowanie polityczne, w drugiej turze wyborów został wsparty przez PO (nie deklaruje członkostwa w PO). 
7) Poznaniu - 4874,34 (reelekcja, II tura);

8) Świnoujściu - 4632,07 (reelekcja, I tura);

9) Krakowie - 4530,07 (reelekcja, II tura);

10) Katowicach - 4501,10 (reelekcja, I tura);

11) Krośnie - 4470,29 (reelekcja, I tura);

12) Gdańsku - 4339,08 (reelekcja, I tura);

13) Kielcach - 4338,53 (reelekcja, I tura);

14) Bielsku Białej - 4298,38 (reelekcja, I tura);

15) Zielonej Górze - 4261,85 (reelekcja, I tura);

16) Nowym Sączu - 4153,11 (reelekcja, I tura);

17) Lesznie - 4136,21 (reelekcja, I tura);

18) Słupsk - 4116,06 (reelekcja, I tura);

19) Zamość - 4105,87 (reelekcja, I tura).

Zestawiając poziom najwyższych wydatków budżetowych na mieszkańca, które ustalono dla 19 spośród 65 miast z uzyskiwanym poparciem wyborczym, wyraźnie zauważalna jest korelacja pomiędzy wysokością wydatków (w ramach tych wydatków są ujęte kwoty przeznaczane m.in. na nowe inwestycje podnoszące poziom życia w mieście) a uzyskiwanym poparciem wyborczym. Spośród 17 prezydentów, aż 15 uzyskało reelekcję w pierwszej turze, $\mathrm{w}$ tej grupie znalazło się 5 prezydentów z rekordowym poparciem wyborczym: Wrocław - 71,62\%, Zabrze - 75,7\%, Krosno - 77\%, Bielsko-Biała - 77,5\%, Zielona Góra - 64,87\%. W tej grupie znalazł się tylko jeden prezydent (PiS), który utracił władzę na rzecz kandydata wspieranego przez PO. Prezydenci Poznania i Sopotu, którzy znaleźli się w obu rankingach (miast, w których są najwyższe kwoty dochodów i wydatków budżetowych) mieli dość skomplikowaną sytuację - w obu przypadkach toczyły się sprawy sądowe ${ }^{8}$. Mimo tego, choć w II turze, wybory wygrali.

Dane dotyczące pozyskanych środków unijnych przez miasta na prawach powiatu, w których zostali wybrani nowi prezydenci w 2010 roku (nie doszło do reelekcji prezydentów) oraz poziom bezrobocia w mieście w okresie przedwyborczym:

8 Prezydent Sopotu - informacje o toczonych postępowaniach sądowych, http://pl.wikipedia.org/wiki/Jacek_Karnowski_(polityk), 17.07.2012. Prezydent Poznania - informacje o toczonych postępowaniach sądowych, http://pl.wikipedia.org/wiki/Ryszard_Grobelny, 17.07.2012. 


\begin{tabular}{|c|c|c|c|}
\hline Lp. & Miasto & $\begin{array}{c}\text { Środki unijne, na koniec } \\
2009 \text { r., pozyskane z puli } \\
\text { na lata: } 2007 / 2013 \\
\text { (w zlotych, na jednego } \\
\text { mieszkańca) }\end{array}$ & $\begin{array}{c}\text { Poziom bezrobocia }(\%) \\
\text { w mieście oraz średnio } \\
\text { (\%) w województwie } \\
\text { - dane na koniec września } \\
2010 \text { r. }\end{array}$ \\
\hline 1. & Bydgoszcz & 514 & $7,6 / 15,5$ \\
\hline 2. & Częstochowa & 930 & $10,9 / 9,6$ \\
\hline 3. & Chorzów & 435 & $11,9 / 9,6$ \\
\hline 4. & $\begin{array}{l}\text { Elbląg } \\
\text { urzędujący prezydent prze- } \\
\text { grał w II turze }\end{array}$ & 1952 & $16,5 / 18,8$ \\
\hline 5. & $\begin{array}{l}\text { Jelenia Góra } \\
\text { urzędujący prezydent prze- } \\
\text { grał w II turze }\end{array}$ & 1581 & $9,6 / 12,7$ \\
\hline 6. & Konin & 712 & $12,1 / 8,9$ \\
\hline 7. & Koszalin & 1131 & $10,5 / 15,9$ \\
\hline 8. & $\begin{array}{l}\text { Lublin } \\
\text { prezydent nie ubiegał się } \\
\text { o reelekcję }\end{array}$ & 2897 & $9,1 / 15,2$ \\
\hline 9. & $\begin{array}{l}\text { Łomża } \\
\text { prezydent w kampanii z za- } \\
\text { rzutami prokuratorskimi } \\
\text { - przegrał wybory }\end{array}$ & 2162 & $14,5 / 12,2$ \\
\hline 10. & $\begin{array}{l}\text { Łódź } \\
\text { Prezydent odwołany w refe- } \\
\text { rendum }\end{array}$ & 1583 & $10,1 / 11,5$ \\
\hline 11. & Mysłowice & 292 & $8,1 / 9,6$ \\
\hline 12. & Płock & 1099 & $10,5 / 9,0$ \\
\hline 13. & Ruda Śląska & 322 & $7,8 / 9,6$ \\
\hline 14. & Świętochłowice & 382 & $15,9 / 9,6$ \\
\hline 15. & Tarnobrzeg & 355 & $13,9 / 15,0$ \\
\hline
\end{tabular}

Środki unijne średnio: 1089,80 zł, bezrobocie średnio: 11,27\%.

Dane dotyczące pozyskanych środków unijnych przez miasta na prawach powiatu, w których prezydenci zostali wybrani w 2010 roku z rekordowym poparciem $\mathrm{w}$ pierwszej turze oraz poziom bezrobocia $\mathrm{w}$ mieście w okresie przedwyborczym: 


\begin{tabular}{||c|l|c|c||}
\hline Lp. & \multicolumn{1}{|c|}{$\begin{array}{c}\text { Miasto - uzyskane } \\
\text { poparcie }\end{array}$} & $\begin{array}{c}\text { Środki unijne, na koniec } \\
\mathbf{2 0 0 9} \text { r., pozyskane z puli } \\
\text { na lata: 2007/2013 } \\
\text { (w zlotych, na jednego } \\
\text { mieszkańca) }\end{array}$ & $\begin{array}{c}\text { Poziom bezrobocia (\%) } \\
\text { w mieście oraz średnio } \\
\text { (\%) w województwie } \\
\text { dane na koniec września } \\
\mathbf{2 0 1 0} \text { r. }\end{array}$ \\
\hline 1. & Białystok $-68,53 \%$ & 3054 & $12,0 / 12,2$ \\
\hline 2. & Bielsko Biała $-77,5 \%$ & 2663 & $5,8 / 9,6$ \\
\hline 3. & Gdynia $-87,7 \%$ & 2294 & $5,4 / 11,8$ \\
\hline 4. & Jaworzno $-64,46 \%$ & 791 & $11,2 / 9,6$ \\
\hline 5. & Krosno $-77 \%$ & 2026 & $7,4 / 15,0$ \\
\hline 6. & Suwałki $-71 \%$ & 1772 & $12,0 / 12,2$ \\
\hline 7. & Wrocław $-71,62 \%$ & 3760 & $5,6 / 12,7$ \\
\hline 8. & Zabrze $-75,7 \%$ & 682 & $12,8 / 9,6$ \\
\hline
\end{tabular}

Środki unijne średnio: 2130,25 zł, bezrobocie średnio: 9,025\%.

Wśród miast, które uzyskały najwyższe kwoty z funduszy unijnych (pow. 2 tys. zł na mieszkańca) na koniec 2009 roku znalazły się:

1) Sopot-5121 (reelekcja, II tura);

2) Kielce - 4037 (reelekcja, I tura);

3) Wrocław - 3760 (reelekcja, I tura);

4) Olsztyn - 3751 (reelekcja, II tura);

5) Rzeszów - 3720 (reelekcja, I tura);

6) Żory - 3160 (reelekcja, I tura);

7) Białystok - 3054 (reelekcja, I tura);

8) Lublin - 2897 (nowy prezydent «PO $\rightarrow \mathrm{PO} »$ od 2010 r., wybór w II turze, poprzedni prezydent nie ubiegał się o reelekcję);

9) Bielsko Biała - 2663 (reelekcja, I tura);

10) Piotrków Trybunalski - 2649 (reelekcja, I tura);

11) Opole - 2554 (reelekcja, II tura);

12) Toruń - 2331 (reelekcja, I tura);

13) Gdynia - 2294 (reelekcja, I tura);

14) Kraków - 2249 (reelekcja, II tura);

15) Łomża - 2162 (prezydent z zarzutami prokuratorskimi, przegrana w wyborach);

16) Krosno - 2026 (reelekcja, I tura);

17) Poznań - 2009 (reelekcja, II tura).

Z kolei wśród miast, które uzyskały najniższe kwoty z funduszy unijnych (poniżej 500 zł na mieszkańca) na koniec 2009 roku znalazły się:

1) Legnica - 465 (reelekcja, I tura); 
2) Dąbrowa Górnicza - 452 (reelekcja, II tura);

3) Grudziądz - 438 (reelekcja, I tura);

4) Chorzów - 435 (nowy prezydent «PO» od 2010 r., wybór w II turze);

5) Sosnowiec - 414 (reelekcja, II tura);

6) Siemianowice Śląskie - 402 (reelekcja, I tura);

7) Świętochłowice - 382 (nowy prezydent «PO» od 2010 r., wybór w II turze);

8) Tarnobrzeg - 355 (nowy prezydent «PO» od 2010 r., wybór w II turze);

9) Zamość - 337 (reelekcja, I tura);

10) Ruda Śląska - 322 (nowy prezydent «org. samorządowa» od 2010 r., wybór w II turze);

11) Rybnik - 318 (reelekcja, II tura);

12) Mysłowice - 292 (nowy prezydent «org. samorządowa» od 2010 r., wybór w II turze);

13) Ostrołęka - 189 (reelekcja, I tura).

Powyższe zestawienia wskazują, że ilość środków pozyskiwanych z funduszy unijnych, co przekłada się na nowe projekty i inwestycje, może wpływać na poparcie uzyskiwane przez prezydentów ubiegających się o reelekcję, albo też wpływać na to, że prezydenci tracą władzę - wśród 13 miast, w których były najniższe kwoty pozyskanych dotacji w 5 przypadkach prezydenci przegrywali wybory. Jednocześnie w grupie miast (17), gdzie kwoty dotacji były najwyższe znalazło się 5 miast, w których prezydenci wygrali wybory w pierwszej turze z rekordowym poparciem uzyskanym w wyborach.

W zakresie analizy średniego poziomu bezrobocia także występują odstępstwa. Poziom bezrobocia w miastach na prawach powiatu, gdzie prezydenci uzyskali najwyższe rekordowe poparcie wygrywając wybory w I turze, bezrobocie wyniosło średnio 9,025\%. Z kolei w miastach, w których wyborcy podjęli decyzje o zmianie na stanowiskach prezydentów, bezrobocie średnio wyniosło $11,27 \%$.

Największe inwestycje zrealizowane w miastach na prawach powiatu na koniec 2009 r.:

1) Warszawa - budowa II odcinka linii metra i trasy mostu północnego, Budowa Centrum Nauki Kopernik - I tura;

2) Gdańsk - połączenie portu lotniczego z portem morskim, połączenie dróg krajowych (trasa Sucharskiego), budowa stadionu piłkarskiego PGE Arena, projekt komunikacji miejskiej, budowa Europejskiego 
Centrum Solidarności, rozbudowa układu komunikacyjnego przy hali sportowej - I tura;

3. Wrocław - budowa stadionu piłkarskiego, zintegrowany system transportu szynowego, budowa Narodowego Forum Muzyki, budowa północnej obwodnicy śródmiejskiej, uzbrojenie terenu osiedla Złotniki i Ołtaszyn - I tura;

4) Łódź - wodociągi i oczyszczalnia ścieków, budowa hali widowiskowej, modernizacja i adaptacja na cele kulturalne i artystyczne byłej elektrociepłowni - prezydent odwołany w referendum;

5) Olsztyn - budowa i modernizacja kanalizacji, budowa i modernizacja transportu zbiorowego, budowa centrum wodno-rekreacyjnego - I tura;

6) Poznań - modernizacja stadionu, budowa kompleksu sportowo-rekreacyjnego Termy Maltańskie - II tura;

7) Tychy - budowa i modernizacja kanalizacji - I tura;

8) Kraków - modernizacja stadionu, budowa stadionu Cracovii, budowa Muzeum Sztuki Współczesnej - II tura;

9) Gdańsk i Sopot - budowa wielofunkcyjnej hali sportowo-widowiskowej (I tura Gdańsk, II tura Sopot);

10) Bydgoszcz - budowa linii tramwajowej - przegrana reelekcja;

11) Katowice - budowa Międzynarodowego Centrum Kongresowego, budowa siedziby Narodowej Orkiestry Symfonicznej, modernizacja hali Spodek - I tura;

12) Bielsko-Biała - poprawa gospodarki wodno-ściekowej, przebudowa stadionu miejskiego, budowa hali sportowo-wystawienniczej - I tura;

13) Zabrze - gospodarka wodno-ściekowa - I tura.

Powyższe dane, obejmujące zarówno najwyższe dochody i wydatki budżetowe oraz kwoty pozyskiwane z UE wskazały na istotność ekonomicznych czynników, które determinują wybory lokalnych liderów, ubiegających się o reelekcję. Powyżej wskazane miasta, to najczęściej duże miasta wojewódzkie, ale największe inwestycje (jak chodzi o środki pozyskane i wydane na ich realizację) realizowano także w mniejszych miastach - Tychy, Bielsko-Biała czy Zabrze. We wszystkich 3 miastach prezydenci wygrali w pierwszej turze, w 2 z rekordowym poparciem. Zasadniczo obserwowalna jest tendencja, że w miastach o dobrej i stabilnej kondycji finansowej oraz stosunkowo wysokim poziomie funduszy pozyskiwanych z UE prezydenci z powodzeniem zapewniają sobie reelekcję, najczęściej już w I turze wyborów. Co warto podkreślić przeznaczanie środków unijnych jest różnicowane pod wzglę- 
dem celów, co oznacza, że środki są wydawane zarówno na infrastrukturę komunikacyjną (drogi, obwodnice, transport zbiorowy), poprawę warunków życia mieszkańców i rozwój cywilizacyjny - budowa i modernizacja kanalizacji, gospodarka ściekowa, jak i projekty związane z kulturą, edukacją i dziedzictwem narodowym. Tym samym zaznacza się różnorodność celów, ale i docieranie z nowymi inwestycjami dedykowanymi dla zróżnicowanych grup mieszkańców, dla których istotne są odmienne cele, które powinny być przez miasto realizowane.

\section{Poparcie wynikające z polityki realizowanej w uchwałach Rad Miasta}

Analizując uchwały rad miast, przyjmowane w roku wyborczym można wskazać na szereg uchwał (dla potrzeb tych rozważań, uchwały zostały pogrupowane), podejmowanych jako uchwały dedykowane poszczególnym grupom wyborców.

Analiza ponad 12 tys. uchwał (podjętych, jako nowe, a niebędących nowelizacjami uchwał wcześniej przyjętych, w okresie styczeń-listopad 2010 r.) wskazała, iż rady miast przyjmowały określone uchwały:

- wspierające idee określonych środowisk (budowa pomników, przyznawanie honorowych obywatelstw, medali i orderów);

- wspierające bezpośrednio określone środowiska (stypendia naukowe, sportowe, za osiagnięcia kulturalne, nagrody dla nauczycieli, finansowanie programów zdrowotnych czy szkoleniowych dla nauczycieli);

- związane z wydatkowaniem pieniędzy publicznych na projekty dedykowane mieszkańcom (np. projekty zdrowotne - dofinansowywane albo darmowe szczepienia dla dzieci, np. szczepienia przeciwko żółtaczce czy HPV dla dziewcząt - koszt szczepionki, to około $1500 \mathrm{zl}$, dofinansowanie zakupu leków przez seniorów, projekty edukacyjne - wspierane pieniędzmi z funduszy UE, zapomogi dla kobiet za urodzenie dziecka, uruchamianie projektów ulg i bonifikat, dedykowanych do rodzin wielodzietnych - rodzina $3+-\mathrm{w}$ różnych miastach projekty mają różną nazwę, ale rozwiązania są podobne);

- wspierające rozwój infrastruktury dedykowanej mieszkańcom, albo zorganizowanym grupom mieszkańców - wieloletnie projekty (np. modernizacji kanalizacji, budowy ścieżek rowerowych, budowy obiektów sportowych czy kulturalnych); 
- doprowadzające do dysponowania majątkiem miasta, na rzecz określonych grup mieszkańców (np. wyprzedaż mieszkań komunalnych z bonifikatą od $90 \%$ do $99 \%$, nieodpłatne albo za symboliczną wartość $1 \%$ przekazywanie nieruchomości placówkom naukowym - w części przypadków stwierdzono, że profesorowie i rektorzy tych placówek naukowych wspierali komitety poparcia urzędującego prezydenta, nieodpłatne albo za symboliczny $1 \%$ wartości przekazywanie nieruchomości na rzecz kościołów i związków wyznaniowych);

- wspierające tworzenie nowych miejsc pracy (zwolnienia od podatku od nieruchomości dla firm tworzących nowe miejsca pracy).

Zaproponowane pogrupowanie podejmowanych przez rady miasta uchwał miało na celu zaprezentowanie, iż rady miasta podejmując uchwały, najczęściej przygotowywane przez administrację prezydenta, mogą wspierać realizację polityki, która pozwala albo na pozyskiwanie potencjalnych, nowych wyborców, albo na utrzymanie poparcia dotychczasowych. Podejmowanie uchwał w roku wyborczym, a więc wtedy, kiedy szczególnie istotne jest, aby wyborcy zauważali aktywność władz miasta skierowaną bezpośrednio do nich poprzez konkretne projekty i uszczegółowione plany na przyszłość, może stanowić istotny czynnik wpływający na uzyskiwane poparcie wyborcze.

\section{Komunikacja polityczna - strony internetowe, polityczne blogi, Facebook, media samorządowe}

\subsection{Social media - Facebook, polityczne blogi i strony internetowe w procesach wyborczych}

Badania wskazały, iż spośród 65 prezydentów polskich miast na prawach powiatu 33 posiada aktywne profile lub fan page, natomiast 32 nie posiada, albo posiada, ale konta są nieaktywne, nie są na nich zamieszczane informacje i nie jest prowadzony dialog z otoczeniem. Kilku prezydentów posiada założone zarówno profile, jak i fan page, najczęściej aktywniej komunikując się z wykorzystaniem jednego z kont. Zdarzają się także sytuacje, jak np. u prezydenta Bytomia (odwołany z inicjatywy mieszkańców w referendum, w czerwcu 2012 r.), że te same treści były publikowane zarówno na profilu, jak i na fan page.

$\mathrm{Z}$ dokonanej analizy wynika, iż posiadanie konta (profilu lub fan page) i prowadzenie komunikacji za jego pośrednictwem nie wpływa na 
uzyskiwanie większego poparcia wyborczego. Tylko 9 prezydentów spośród 33 posiadających konto na Facebooku zostało wybranych, w listopadzie 2010 roku, w pierwszej turze, uzyskując minimum $50 \%$ poparcie wyborcze. Natomiast aż 23 prezydentów spośród 32, którzy albo w ogóle nie posiadają konta na Facebooku, albo nie prowadzą aktywnej komunikacji z otoczeniem za jego pośrednictwem, uzyskało poparcie wyborcze w pierwszej turze.

Badania wskazały także, że ci prezydenci, którzy uzyskali rekordowo wysokie poparcie wyborcze, wygrywając wybory w pierwszej turze, jak prezydenci: Gdyni - 87,5\%, Bielska-Białej - 77,5\%, Krosna - 77\%, Zabrza - 75,7\%, Suwałk - 71\% nie posiadają w ogóle albo posiadają nieaktywne (niewykorzystywane podczas kampanii wyborczej) konta na Facebooku. To dodatkowo potwierdza, iż komunikacja prowadzona z wykorzystaniem Facebooka, czy informacje przekazywane za pośrednictwem tego medium społecznościowego, nie maja jeszcze istotnego znaczenia dla uzyskiwanego poparcia wyborczego. Takie same wnioski formułowane są w wyniku badań prowadzonych w innych krajach i jak wskazuje van Dijk: „Telewizja wciąż odgrywa w polityce znacznie istotniejszą rolę niż Internet, ale dla grupy młodych wyborców sieć jest równie ważna, jak stare media",

Kolejnym z elementów zrealizowanego badania była analiza treści zawieranych na tablicach prezydentów lub kandydatów na prezydentów w kampanii wyborczej oraz ich aktywność w dyskusjach, które nawiązywały się po opublikowaniu treści. Badania wskazały, iż spośród 33 prezydentów posiadających konta na Facebooku 14 bierze udział w dyskusjach dotyczących informacji, które opublikowali na swoich tablicach, z czego 4 prezydentów jest aktywnych, zaś 10 wzięło udział sporadycznie w prowadzonych dyskusjach. Do najbardziej aktywnych w dyskusjach dotyczących opublikowanych informacji zaliczyć należy prezydentów należących do Platformy Obywatelskiej (3) oraz do Prawa i Sprawiedliwości (1), choć ten ostatni aktywny był wyłącznie w kampanii wyborczej, pozostali w ten sposób budowali regularną komunikację z mieszkańcami. W tym zakresie, choć to zbyt mała grupa, aby wyciągać wnioski, dała się zauważyć pewna prawidłowość. Mianowicie, prezydenci, którzy ubiegali się o reelekcję (prezydent Gdańska i prezy-

9 J. van Dijk, Społeczne aspekty nowych mediów, Wyd. PWN, Warszawa 2010, S. 150 . 
dent Grudziądza) aktywni i zaangażowani w dyskusjach z mieszkańcami na tematy które dotyczą miast, wygrywali wybory w pierwszej turze, natomiast prezydent Radomia, ubiegający się o reelekcję i zaangażowany w debatę wyłącznie podczas kampanii wyborczej, ignorujący zaś komunikacje podczas sprawowania mandatu, wygrał wybory, ale dopiero w drugiej turze.

Badania potwierdziły także, iż aktywność prezydentów w zamieszczaniu informacji na swoich kontach (profilach lub fan page) oraz ewentualnym, nawet sporadycznym podejmowaniu dyskusji z osobami komentującymi zamieszczane informacje na ich tablicach wzrasta w okresie kampanii wyborczej. Znaczna część kont aktywizuje się właśnie w tym okresie, ale badania ujawniły, iż np. prezydent Gdańska, jako jedyny jest bardzo aktywny w procesach komunikacji zarówno podczas sprawowania mandatu, jak i w trwającej kampanii, i to zarówno w liczbie zamieszczanych informacji, jak i uczestnictwie w debatach, które są toczone po opublikowaniu informacji na tablicy. To oznacza, że w przypadku prezydenta Gdańska można stwierdzić, iż komunikacja polityczna, którą prowadzi z mieszkańcami nie jest komunikacją przypadkową, nie ma na celu osiagania jedynie celów wyborczych, ale stwarza wrażenie rzeczywistej płaszczyzn debaty publicznej o sprawach lokalnych, także podczas sprawowania mandatu.

To może oznaczać, że Facebook, jako przykład wykorzystania medium społecznościowego może mieć znaczenie wyborcze i być źródłem uzyskiwanego poparcia wyborczego w przypadku, w którym stanowi ono celowo, systematycznie i aktywnie wykorzystywane narzędzie przez lokalnego polityka. Bagatelizowanie przez polityka udziału w dyskusji i publikacja informacji na tablicy, zwłaszcza intensywnie w okresie prowadzonej kampanii wyborczej, wyborcy mogą traktować jako kolejne narzędzie wykorzystywane $\mathrm{w}$ marketingu politycznym, a nie takie dzięki któremu rzeczywiście istnieje możliwość komunikacji z politykiem. Profil czy fan page prezydenta, jeśli ma charakter publiczny i służy zamieszczaniu w nim informacji urzędowych, powinien stanowić płaszczyznę debaty publicznej o sprawach lokalnych i powodować aktywizację lokalnej społeczności wokół spraw dla niej ważnych. Bagatelizowanie tej formy komunikowania, jako także możliwości aktywizacji lokalnej społeczności, staje się jednym z powodów dla którego media społecznościowe, w tym Facebook, nie oddziałują na partycypację polityczną nie wywołując zmian m.in. w niskiej frekwencji wyborczej w Polsce. 
Także badacze nowych mediów - van Dijk czy Castells zaznaczają relatywnie niski wpływ nowych mediów na kreację wizerunku polityków czy aktywizację społeczności w procesach komunikacji politycznej, jednak zaznaczają, iż jest to stan powoli zmieniający się. Co oznacza, że traktowanie aktywności w nowych mediach w kolejnych latach może wpływać coraz istotniej, także na procesy komunikacji politycznej, w tym, podczas kampanii wyborczych. Analizując komunikację polityczną za pośrednictwem Facebooka i wskazując ważność tego serwisu dla procesów w skali globalnej, ale i lokalnej Mike Westling zaznacza, iż to właśnie za pomocą tego medium politycy mają możliwość komunikowania się ze wszystkimi członkami lokalnej społeczności, którzy są zainteresowani, aby polityków wysłuchać, ale jednocześnie ci sami członkowie lokalnej społeczności mają także prawo do wyrażenia swoich opinii związanych z zarządzaniem lokalną społecznością. Westling szukając uzasadnienia dla takiego wykorzystania Facebooka znajduje je w definicji „sfery publicznej” Jurgena Habermasa, a więc traktuje jako miejsce, w którym odbywa się komunikacja polityczna pomiędzy obywatelami ${ }^{10}$.

Westling zwraca uwagę ponadto na możliwości, które Facebook daje - wykorzystując tablicę (miejsce publikacji informacji), jako lokalny biuletyn, gazetę, miejsce nieformalnych spotkań i wymiany myśli dotyczących spraw publicznych (town hall meeting), także niezależnie od miejsca, w którym się samemu przebywa. Nie bez znaczenia coraz częściej określa się dyskusje odbywające się za pośrednictwem serwisów społecznościowych jako nową agorę.

Traktowanie tablicy jako miejsca publikowania informacji, ale także miejsca, w którym zamieszczane informacje mogą być komentowane przez pozostałych użytkowników, pozwala na stopniowe zastępowanie idei mediów samorządowych poprzez wykorzystanie Facebooka. Korzyści z zastępowania dotychczas stosowanych narzędzi w procesach komunikacji politycznej na szczeblu lokalnym - mediów samorządowych przez uruchamianie fan page'ów na Facebooku pozwala na osiaganie dwóch istotnych z punktu widzenia samorządu celów. Pierwszy to racjonalizacja wydatków. Rezygnacja z emisji mediów samorządowych w formach tradycyjnych (obecnie najpopularniejsza w miastach na prawach powiatu wciąż jest gazeta) na rzecz publikowania informacji na tablicy Face-

10 M. Westling, Expanding the Public Sphere. The Impact of Facebook on Political Communication, http://www.mendeley.com/research/expanding-the-public-sphere-the-impact-of-facebook-on-political-communication/. 
booka, to oszczędność pieniędzy, które pozostają w budżecie gminy, gdyż usługi Facebooka są darmowe. Drugi cel, który wydaje się w kontekście budowania płaszczyzny do debaty publicznej jeszcze istotniejszy, to fakt, że publikowanie informacji daje użytkownikom prawo do wypowiadania opinii o opublikowanych treściach, polemizowania z nimi, kontrargumentowania. Innymi słowy, dzięki Facebookowi można mówić o tworzeniu rzeczywistej lokalnej agory, przestrzeni publicznej, w której następuje wymiana informacji i dyskusja nad opublikowanymi treściami. Dopuszczenie do otwartej dyskusji o sprawach lokalnych pozwala także na unikanie podejrzeń czy zarzutów, pojawiających się obecnie w stosunku do mediów samorządowych o stronniczości, manipulacji oraz propagandzie informacyjnej.

Z kolei analiza wykorzystania politycznych blogów i stron internetowych wskazała, iż spośród 65 prezydentów miast na prawach powiatu w kampanii wyborczej w 2010 r. z komunikacji z wykorzystaniem stron i blogów (oba narzędzia) korzystało 13 prezydentów, tylko strony wykorzystywało 15 prezydentów, tylko blogi 7, zaś ani strony ani bloga w ostatniej kampanii nie miało 30 prezydentów. Podobnie, jak w przypadku komunikacji z wykorzystaniem Facebooka, prezydenci w kampanii wyborczej byli zdecydowanie bardziej aktywni w komunikacji za pośrednictwem strony czy bloga niż w okresie sprawowania władzy (np. prezydent Krakowa w roku wyborczym - 2010 zamieścił prawie 90 wpisów na blogu, w kolejnym 2011 roku - 26). Część stron i blogów nie jest aktualizowana po wyborach, ostatnie wpisy są dokonane w listopadzie albo w grudniu 2010 roku. Prezydenci, którzy w kampanii wyborczej uzyskali rekordowe poparcie wygrywając w pierwszej turze - Gdynia, Bielsko-Biała, Krosno, Suwałki, Jaworzno, Białystok - nie korzystali zupełnie z komunikacji via social media, tylko prezydent Zabrza wykorzystywała stronę internetową oraz blog w kampanii wyborczej. Część blogów pozwala na umieszczanie w nich komentarzy, część nie np. blog prezydenta Olsztyna, natomiast blog prezydenta Krakowa formalnie pozwala na dokonywanie komentarzy, ale analiza wpisów z dwóch lat (2010-2011) wskazała brak komentarzy. Inaczej jest na blogach prezydentów Poznania i Gdańska, gdzie opublikowane komentarze są utrzymywane, także te negatywne. W przypadku blogów prowadzonych przez prezydentów Chorzowa i Bytomia istnieje możliwość komentowania, ale jest wykorzystywana przez czytelników zaledwie sporadycznie.

Treści publikowane na stronach internetowych odnoszą się zasadniczo do prezentowania programów wyborczych, zrealizowanych $\mathrm{w}$ po- 
przednich latach inwestycji na rzecz rozwoju miasta i projektów np. kulturalnych, dedykowanych mieszkańcom, część stron zawiera także poparcie wyrażane przez osoby znane i rozpoznawalne, albo osoby zdolne do pozyskiwania kapitału społecznego, potencjalnie popierającego prezydenta. Wśród takich osób najczęściej znajdują się: sportowcy, aktorzy, muzycy, przedsiębiorcy, naukowcy, dyrektorzy szkół, przedstawiciele związków zawodowych, a w przypadku prezydenta ubiegającego się o reelekcję lub kandydata na prezydenta ubiegającego się o zdobycie władzy, jeśli osoby te należą do partii politycznych - poparcie liderów partii lub innych polityków, należących lub wspierających partię i cieszących się uznaniem społecznym. W przypadku kandydatów PO, wspierającymi byli m.in. prof. Jerzy Buzek - eurodeputowany, w czasie przed wyborami w 2010 r. - przewodniczący Parlamentu Europejskiego, w przypadku SLD - Aleksander Kwaśniewski, były prezydent. Na ile poparcie wyrażane przez liderów opinii ma wpływ na podejmowane decyzje wyborcze jest trudno ustalić. Z pewnością jest nie bez znaczenia dla kandydatów ubiegających się o urząd prezydenta po raz pierwszy, jeśli chodzi o poparcie liderów partyjnych. Ten wniosek można wysnuć, analizując wcześniejsze ustalenia, jak istotne znaczenie dla kandydata ma poparcie płynące z partii politycznej, zwłaszcza sprawującej władzę w czasie wyborów samorządowych.

\subsection{Media samorządowe}

Kolejnym obszarem, który związany jest z procesami komunikacji na poziomie lokalnym są wciąż popularne w Polsce media samorządowe, czyli emitowane albo bezpośrednio przez władze miasta, albo za pośrednictwem spółek komunalnych. Jak wskazały badania, przeprowadzone w 2010 roku w miastach na prawach powiatu, w 73\% zbadanych miast (w badaniu wzięło udział $40 \%$ polskich miast na prawach powiatu) posiadało własne media, które emitowane są w formie: portalu internetowego (innego niż Biuletyn Informacji Publicznej - obowiązkowo posiadany przez administrację publiczną czy strona internetowa urzędu) - 7 wskazań, gazety - 15 wskazań, telewizji -3 wskazania $^{11}$. Żadne

11 Badania zostały przeprowadzone przy wykorzystaniu kwestionariusza ankiety. Wyniki badań zacytowano w treści tego tekstu, choć obszar badawczy był zawężony (w badaniu wzięło udział 40 procent miast) w stosunku do badań dotyczących 
miasto nie emitowało $\mathrm{w}$ czasie prowadzenia badania medium samorządowego w formie radia. W 6 przypadkach miasta emitują media samorządowe $\mathrm{w}$ dwóch formach, jako portal internetowy oraz $\mathrm{w}$ formie gazety, w 1 przypadku miasto prowadzi zarówno portal, wydaje gazetę, jak i przekazuje informacje za pośrednictwem własnej telewizji. Badane miasta wskazały powody, dla których emitują media samorządowe. I tak głównym powodem emitowania własnych mediów ${ }^{12}$ jest chęć informowania o planach działań samorządu (18 wskazań), możliwość przekazywania pełnego uzasadnienia podejmowanych decyzji (14 wskazań) oraz budowanie pozytywnego wizerunku władzy lokalnej (13 wskazań). Zdecydowanie mniej wskazano odpowiedzi uzasadniających emisję mediów samorządowych, jako przesłanki dla budowania więzi pomiędzy mieszkańcami a władzą samorządową (8 wskazań) oraz stworzenia możliwości dla mieszkańców, aby wypowiadali własne opinie na forum publicznym (6 wskazań). W 8 przypadkach zaznaczono odpowiedź, iż emisja mediów samorządowych jest wywołana koniecznością publikacji komunikatów obowiązkowych, a w 4 przypadkach wskazano, iż chodzi o możliwość publikowania sprostowań do informacji nieprawdziwych, wyemitowanych w innych mediach. $Z$ tego wynika, że emisja mediów samorządowych zmierza do informowania mieszkańców oraz budowania wizerunku lokalnych polityków, którzy sprawują władzę. Nie jest natomiast równie istotnym powodem wykorzystywanie mediów samorządowych, jako płaszczyzny do kreacji lokalnej debaty publicznej, wymiany poglądów czy zachęcania mieszkańców do aktywnego wypowiadania się na tematy lokalne.

Z kolei podstawowymi powodami deklarowanymi przez miasta, które nie emitują własnych mediów (7 miast) jest brak środków finansowych na taką działalność ( 5 wskazań), dobra współpraca z innymi mediami, tj. publicznymi i komercyjnymi (2 wskazania) oraz uznanie takiej aktywności za formę propagandy (3 wskazania).

Badania wskazały ponadto, iż media samorządowe w 13 przypadkach są emitowane bezpośrednio przez urząd miasta, w 4 przez spółki gminne - z czego w 3 przypadkach spółki gminne zajmują się także inną działalnością, nie tylko wydawaniem mediów samorządowych,

wykorzystania Facebooka w procesach komunikacji prezydentów i miast (tym badaniem objęto 100 procent miast na prawach powiatu).

${ }^{12}$ Liczba odpowiedzi nie sumuje się, miasta miały prawo wskazać kilka odpowiedzi. 
w 1 przypadku jedyną działalnością spółki jest emisja mediów. We wszystkich 4 przypadkach, w których media są emitowane przez spółki gminne, miasta posiadają zdecydowaną albo pełną własność spółki - w trzech przypadkach jest to $100 \%$ własności miast, w jednym $99,77 \%$, a w jednym $80 \%$. W 2 przypadkach media są emitowane w inny sposób, tj. miasto finansuje wydawanie dodatku informacyjnego w prasie komercyjnej oraz gazeta jest wydawana przez jeden z ośrodków kultury podległych urzędowi miasta.

Miasta zapytano także, czy media samorządowe w kolejnych dwóch latach (badano lata 2009 i 2010 - rok wyborów samorządowych) zorganizowały debaty i czaty internetowe. Spośród 17 miast, w których istnieją media samorządowe, tylko $\mathrm{w}$ dwóch zorganizowano debaty - w 2009 roku - łącznie 3 debaty, zaś w 2010 - łącznie 6 debat. Debaty odbywały się bez udziału publiczności. Natomiast, jak chodzi o liczbę odbytych czatów internetowych, te także zostały zorganizowane tylko przez dwa media samorządowe, zarówno w 2009 roku, jak i w 2010 roku - odbyło się po 6 czatów, wszystkie z udziałem rządzących prezydentów.

Natomiast w mediach komercyjnych, w analogicznym czasie, w 8 miastach (bo tylko tyle miast podało dane) odbyło się: w 2009 roku 24 debaty, natomiast w 2010 - 41 debat (rok wyborczy). Tematyka debat organizowanych w mediach komercyjnych była poświęcona analizie spraw bieżących oraz zagadnieniom trwającej kampanii wyborczej (dotyczy 2010 roku). O organizację czatów w mediach komercyjnych badanych miast nie pytano.

Badania wskazały także interesującą zależność, iż z mediów samorządowych najczęściej korzystają ci prezydenci, którzy sprawują władzę z ramienia Sojuszu Lewicy Demokratycznej oraz prezydenci popierani przez lokalne komitety wyborcze, niezwiązane z żadną partią polityczną. Dane dotyczące okresów, od kiedy prezydenci miast rządzą oraz tego faktu, że istnieją media samorządowe można wskazać, iż w przypadku prezydentów niezależnych, czyli niereprezentujących żadnej partii politycznej, w 5 przypadkach prezydenci rządzą miastami od 2002 roku (posiadając media samorządowe), wcześniej niż od 2002 roku rządzi 4 prezydentów dysponujących mediami samorządowymi, od 2006 roku rządzi 3 prezydentów niezależnych, także dysponując mediami samorządowymi. W tej grupie tylko dwóch prezydentów rządzi od 2002 roku nie dysponując mediami samorządowymi (Jaworzno i Legnica). Jak chodzi o prezydentów wspieranych przez Sojusz Lewicy Demokratycznej 
1 prezydent rządzi od 1998 roku, dysponując mediami samorządowymi, kolejny od 2002 także, dysponując mediami samorządowymi, natomiast 3 od 2010 roku (media istniały wcześniej). W przypadku prezydentów należących do Platformy Obywatelskiej w 3 przypadkach istnieją media samorządowe i prezydenci rządzą: od 1998 r., od 2006 r. i od 2010 r. Natomiast w 4 przypadkach miasto nie emituje mediów samorządowych i w 3 przypadkach prezydenci z Platformy Obywatelskiej objęli władzę w 2010 r., jeden sprawuje władzę od 2002 roku.

Przytaczając powyżej wskazane dane, odnośnie wykorzystania Facebooka w procesach komunikacji politycznej, należy zaznaczyć, iż nie potwierdziły one, że komunikacja prowadzona z wykorzystaniem profilu czy fan page prezydenta wpływa na uzyskiwane poparcie wyborcze w takim stopniu, aby umożliwiało wygraną w wyborach w pierwszej turze. Natomiast zestawiając wygraną prezydentów w pierwszej turze z wykorzystywaniem w procesach komunikacji Facebooka oraz emitowanych mediów samorządowych osiagnnięto wynik, z którego wynika, iż w 4 przypadkach prezydenci, którzy korzystali z mediów samorządowych, a nie korzystali z komunikacji z wykorzystaniem Facebooka wygrali wybory w pierwszej turze, w 6 przypadkach korzystali zarówno z Facebooka, jak i mediów samorządowych, w 2 nie korzystali ani z Facebooka, ani mediów samorządowych i w ani jednym przypadku nie zaistniała sytuacja, w której korzystali z Facebooka, ale nie z mediów samorządowych. Z tego wynika, że zdecydowanie częściej, w miastach, które badano pod względem korzystania $\mathrm{z}$ mediów samorządowych, wygrana $\mathrm{w}$ pierwszej turze związana jest $\mathrm{z}$ wykorzystaniem $\mathrm{w}$ procesach komunikacji mediów samorządowych, a nie korzystaniem z Facebooka.

Warto przy cytowanych badaniach, w zakresie powodów, dla których miasta nie emitują własnych mediów wskazać, iż najczęstszym powodem jest brak środków na emisję tych mediów oraz uznawanie, iż przekazy za pośrednictwem takich mediów, to forma propagandy. Tymczasem komunikacja za pośrednictwem Facebooka eliminuje oba te problemy, o czym już wspomniano wcześniej. Prowadzenie komunikacji na fan page miasta jest bezpłatne, a w przypadku przekazów, które mają charakter propagandowy istnieje możliwość ich oceny i komentowania przez odbiorców informacji, co w znacznym stopniu może łagodzić zamiary emitowania przekazów jednokierunkowych, ale także mobilizować władzę do próby przekonywania obywateli, aby wspierać określone projekty. Także Facebook, jako kanał prowadzenia komunikacji mającej na celu aktywizowanie lokalnych społeczności w procesach komuniko- 
wania politycznego wydaje się odpowiadać zmianom społecznym i przenoszeniu się komunikacji ze sfery realnej do sfery wirtualnej.

\section{Podsumowanie - polityka korzyści i racjonalny wybór elektoratu}

Przeprowadzone badania pozwoliły wskazać na kilka prawidłowości dotyczących źródeł poparcia uzyskiwanych przez lokalnych liderów:

1. Maleje rola lokalnych organizacji politycznych w kreacji lokalnych liderów zdolnych do objęcia władzy na rzecz rosnącego znaczenia poparcia, które płynie z poparcia partii politycznych (z kontekstu tego badania ujawniona została znacząca rola poparcia, którego udzielała kandydatom PO - partia sprawująca władzę w Polsce w 2010 r., do badań zrealizowanych $\mathrm{w}$ przyszłości pozostaje odpowiedzieć na pytanie czy poparcie które płynęłoby z innej partii, która sprawowałaby władzę w okresie wyborów, miałoby podobny charakter).

2. Referenda, w wyniku których skutecznie odwołano prezydentów miast nie są źródłem kreacji nowych liderów politycznych - organizatorzy referendów lub partie polityczne wspierające organizatorów referendów nie posiadały na tyle silnych liderów (ani nie były w stanie takich liderów wykreować), którzy byliby do zaakceptowania przez lokalne społeczności, aby po odwołaniu prezydentów w referendach przejąć władzę.

3. Istotnym źródłem poparcia, które płynie dla prezydentów ubiegających się o reelekcję są wyniki ekonomiczne, jakie miasta generuja, w tym także pozyskiwane środki unijne, dzięki którym możliwa jest realizacja inwestycji, projektów dedykowanych poszczególnym grupom mieszkańców.

4. Kolejnym istotnym źródłem generującym poparcie wydają się podejmowane uchwały, dzięki którym zaspokaja się potrzeby albo oczekiwania określonych grup mieszkańców, zwłaszcza uchwały dedykowane bezpośrednio wyborcom, które podejmowane są w roku wyborczym.

5. Komunikacja polityczna z wykorzystaniem social mediów (polityczne blogi i Facebook), stron internetowych oraz mediów samorządowych nie wskazuje jednoznacznie tych narzędzi jako źródeł poparcia wyborczego dla prezydentów. Przekazy formułowane do opinii publicznej zasadniczo mieszczą się w obszarze komunikacji związanej $\mathrm{z}$ informowaniem o zrealizowanych inwestycjach czy projektach, np. 
społecznych czy kulturalnych adresowanych do lokalnej społeczności, osiagnięciach, które miasto albo prezydent indywidualnie osiąga. Wszystkie badane media zasadniczo nie służą władzom lokalnym, poza nielicznymi wyjątkami jak np. prezydent Gdańska, do prowadzenia dialogu z lokalną społecznością. Jednak analiza treści, którą także na potrzeby badania zrealizowano nie wykazała także zaangażowania mieszkańców w próby prowadzenia dialogu z władzą samorządową - np. komentując wpisy na blogach czy na Facebooku. To potwierdza zatem także niski poziom zaangażowania mieszkańców w sprawy lokalne i brak umiejętności debatowania nad nimi.

Reasumując powyższe wyniki badań oraz wnioski na ich podstawie i osadzając te rozważania w kontekście wspomnianej na początku stosunkowo niskiej frekwencji wyborczej, która nie przekracza średnio 50\% (w I turze) i $30 \%$ (w II turze), co wskazuje na niski poziom zainteresowania lokalnych społeczności tym, kto rządzi i jakie podejmuje decyzje, można wskazać, iż prezydenci miast, o ile nie zachodzą szczególne okoliczności jak np. zarzuty prokuratorskie dla prezydenta lub znacznie pogarszająca się sytuacja gospodarcza, brak nowych inwestycji, które są miarą rozwoju, raczej mogą liczyć na reelekcję. Badania potwierdzaja, że to względy racjonalne mają znaczenie dla wyborów dokonywanych przez tę część lokalnych społeczności, która bierze w nich udział. Potwierdza to nie tylko wagę, jaką przykłada się do warunków życia w mieście i pozyskiwanych środków unijnych na realizację inwestycji, ale także racjonalizm, jak chodzi o postrzeganie kandydatów na prezydentów wspieranych przez konkretne partie polityczne. Podkreślanie tych elementów jest także istotne w procesach komunikowania się liderów lokalnych ze społecznościami - takie przekazy dominują w komunikacji prowadzonej zarówno na stronach internetowych, blogach, jak i w postach na Facebooku. Tendencja do podejmowania wyborów racjonalnych w zachowaniach wyborczych staje się coraz bardziej powszechna, nie tylko w Polsce, o czym wspomina Radosław Markowski ${ }^{13}$.

Przeprowadzone badania miały charakter uogólniony, wskazujący kryteria i źródła poparcia wspólne dla liderów politycznych miast na prawach powiatu. Dla wskazania szczególnych kryteriów obejmujących uwarunkowania w poszczególnych miastach, badania powinny być kon-

13 Więcej we wstępie autorstwa Radosława Markowskiego, w: Zachowania Polityczne, red. R. J. Dalton, H. D. Klingemann, Wyd. Naukowe PWN, Warszawa 2010, s. 22 i nast. 
tynuowane, tak by konkretyzować wnioski, które dalej będą użyteczne w projektowaniu skonkretyzowanych kampanii wyborczych. Wśród tych warunków, które powinny być uwzględnione w konkretnych badaniach powinny z pewnością znaleźć się te, dotyczące względów kulturowych, dominujących w lokalnej społeczności oraz uwarunkowań strukturalnych, wynikających powiązań istniejących w lokalnej polityce realizowanej w podległych instytucjach, w spółkach komunalnych czy w samym urzędzie miasta.

\title{
The sources of election support for local leaders in election campaigns for local governments (based on the example of the election campaigns of the presidents of cities with district rights in 2010)
}

\begin{abstract}
Summary
The paper attempts to order and indicate the most important sources of systemic and non-systemic support allowing local leaders to win elections and thereby gaining or maintaining power. The study is concentrated solely on the examination of the sources of support for political leaders in cities with district rights in the 2010 election campaign. The study was financed by a grant from the Ministry of Science and Higher Education obtained for statutory research at the Andrzej Frycz Modrzewski Krakow University in 2012. The paper also makes use of a portion of studies carried out and published earlier on the topic of the processes of political communication of local leaders in the social media (Facebook and political blogs) and on various Internet websites. The paper presents a full account of the results of these studies in the context of political communication in the election process.
\end{abstract}


